\title{
DRAINAGE AND LIGHTING SYSTEM DESIGN IN ZODIA PARK, PETUKANGAN UTARA, SOUTH JAKARTA
}

\author{
Nifty Fath and Harfa Iskandaria \\ Universitas Budi Luhur, Indonesia. \\ nifty.fath@budiluhur.ac.id
}

\begin{abstract}
Zodia Park is one of the city park located in South Jakarta. As a green open space, Zodia Park have some great benefits for community. At now, Zodia Park conditions do not have lighting system that complies with safety standards. The lighting system in this park is still provided by residents independently. Moreover, during heavy rain, the park will be inundated between $20-30 \mathrm{~cm}$. It is because the Zodia Park is located at near inspection river. Thus, in this community service, the team proposes the drainage and lighting system design as a contribution to Forestry Office who maintains the Zodia Park to overcome this problem.
\end{abstract}

Keywords: Drainage, Lighting, Park, Community Service

\section{INTRODUCTION}

Open space is an elongated area or pathway where plants grow both naturally and intentionally planted. The main function of open space itself is to increase the harmony of the urban environment as a safe, comfortable, fresh, beautiful and clean urban facility. Spatial planning is a process system that aims to organize the space usage such as open space. An example of space utilization in urban area is green open space. Some benefits of green open space are described below:

a. Green open space can be said as 'a city's lung'. Plants can absorb the carbondioxide, increase the oxygen levels, add coolness and shade, maintenance of groundwater supplies.

b. The best place for children to play and for family to recreation and to do some exercise such as cycling, walking, jogging, and so on.

c. With green open space, the asthetic value of a city can $\mathrm{s}$

d. ignificantly increase.

e. Green open space can be used as a place for children to play and study, also as a good place for families to recreation, do some exercises, and so on.

City park, as one of the green open space type, is the elements that comprise urban space needed by the community. As an open space, a city park is understood as a space that contains natural elements and scenery caused by the diversity of vegetation, activities and artificial elements provided as social and recreational facilities.

As a green open space, city park can be functioned as an environmental park, recreational park and urban forest. City park can also be used as a decisive element of land used in securing river banks and groundwater catchment areas, and as a city attraction related to the existence of parks as public open spaces for their people. The aim of this research is to provide planning services to the DKI Jakarta Parks and Cemeteries Office in order to improve the utility system in the Zodia park, especially in the drainage system and artificial lighting system.

\section{ZODIA PARK PROFILE}

At present, Petukangan Utara Village has some parks, one of them named Zodia park which was inaugurated in 2015. Zodia Park is located in Jalan H. Doel No.56-57, RT.6/RW.1, Petukangan Utara, Pesanggrahan, South Jakarta, DKI Jakarta 12260 and is under the auspices and maintenance of Forestry Office, South Jakarta. Zodia Park is bordered by:

- North : Temporary Trash Disposal of Petukangan Utara Village

- East : Jalan H. Doel

- South : Aliyah Madrasah Negeri 19 Jakarta

- West : Inspection river, as shown in Figure 1.

As for the drainage system in this park is still not available. Thus, during heavy rain, the park will be inundated between $20-30 \mathrm{~cm}$, as shown in Figure 2 and Figure 3. Even for the drainage system the surrounding environment also passes through this park because the location of this park is adjacent to the river. 
Moreover, until now, the Zodia park conditions do not have lighting system that complies with safety standards. This is because the lighting system in this park is still provided by residents independently. The cable used to connect the lamp to the power source also still uses indoor cables, as shown in Figure 4.

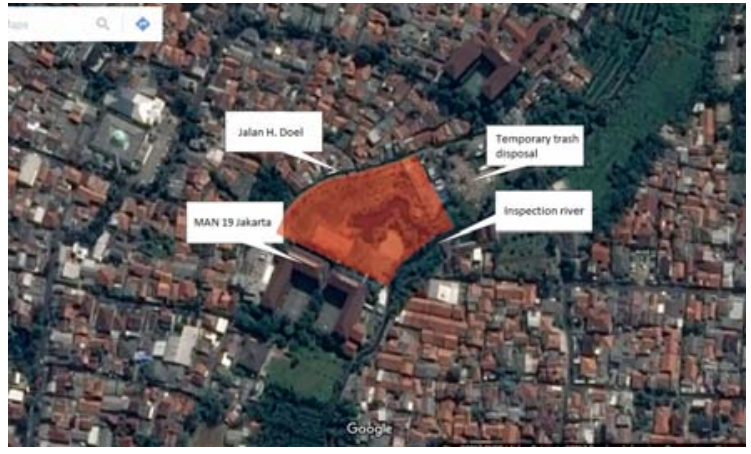

Figure 1. Zodia Park Location

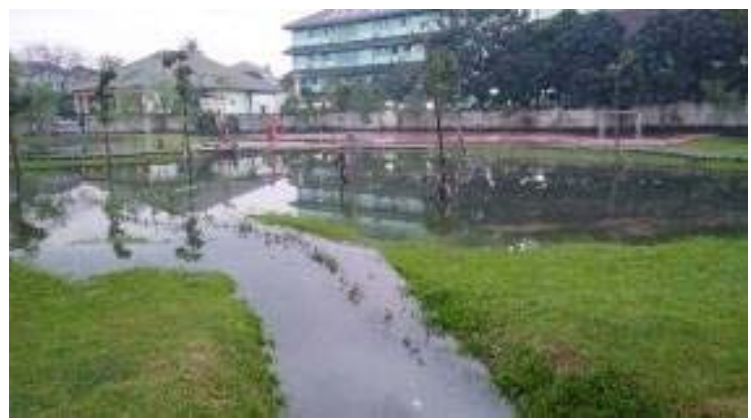

Figure 3. Condition of Zodia Park after rain

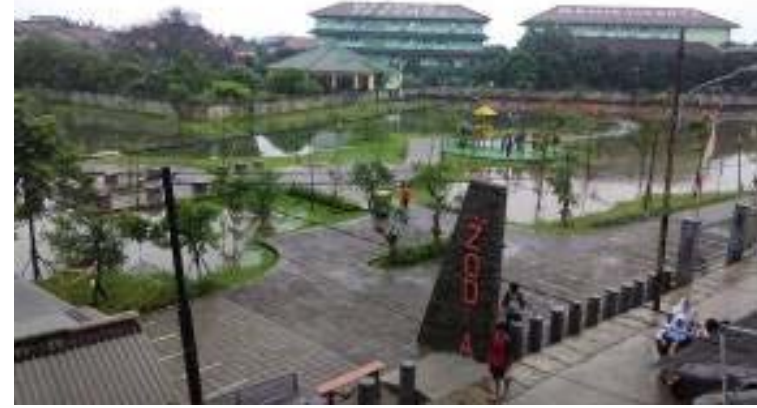

Figure 2. Zodia Park from above

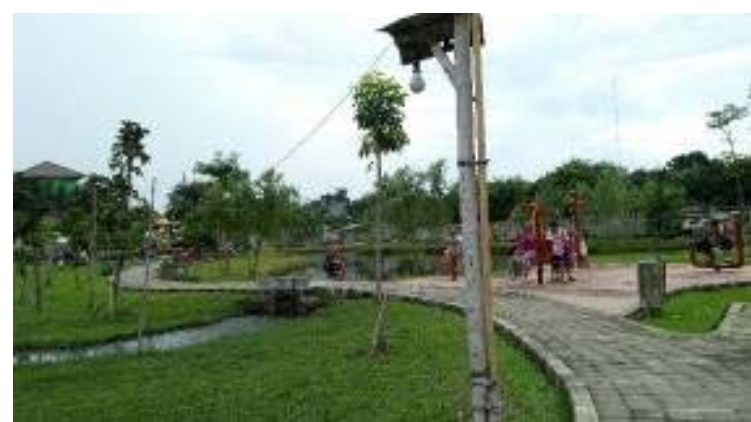

Figure 4. Lighting system in Zodia Park

\section{METHODOLOGY}

The method that used in this community service is giving a workshop about proposed drainage system and lighting system design in Zodia Park to Forestry Office, South Jakarta. The main objectives of the design are to reduce inundation and improve existing lighting system. Design services include the manufacture of waterlogging prevention modeling systems and manufacturing of lighting systems modeling in the Zodia park.

The drainage system are designed by making 3-dimensional modeling using 3D Max software. Both of proposed design are visually explained by using posters and story boards to the Forestry Office. Thus, it can be easy to understand how the utility planning model is at the Zodia park.

\section{IMPLEMENTATION Drainage System}

In this park planning system, the utility system is presented by designing the absorption rainwater system in the form of biopores. Biopores aim to manage excess water by absorbing the water into the soil naturally and quickly so as to increase the underground water layer. In addition to the utility system, there is also a drainage system which aims to speed up the drainage on the puddle of water, to control the erotion, and to control the road damage.

The drainage system design uses standardized precast channels which have been standardized in SNI 03-69662003, as described in Tabel 1 and illustrated in Figure 5 in 2D and Figure 6 in 3D ways. Perforated precast rainwater channel aims to anticipate the water catchment area reduction that stagnate in the drainage. 
Table 1. Perforated precast rainwater channel spesification

\begin{tabular}{|c|l|c|}
\hline No. & \multicolumn{1}{|c|}{ Spesification } & Value (mm) \\
\hline $\mathbf{1 .}$ & Channel Size : & 500 \\
& Long & 530 \\
& Top width & 370 \\
& Bottom width & 480 \\
\hline $\mathbf{2 .}$ & High & 25 \\
\hline $\mathbf{3 .}$ & Concrete Thickness & \\
& Channel hole size : & 110 \\
& Long & 20 \\
& Wide & 50 \\
& Distance between holes & \\
\hline
\end{tabular}

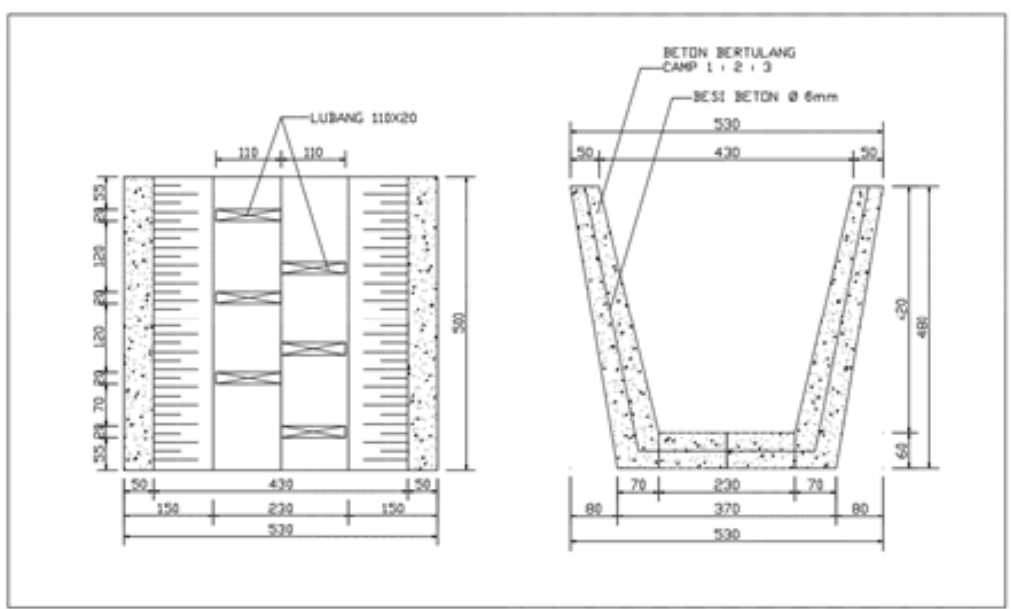

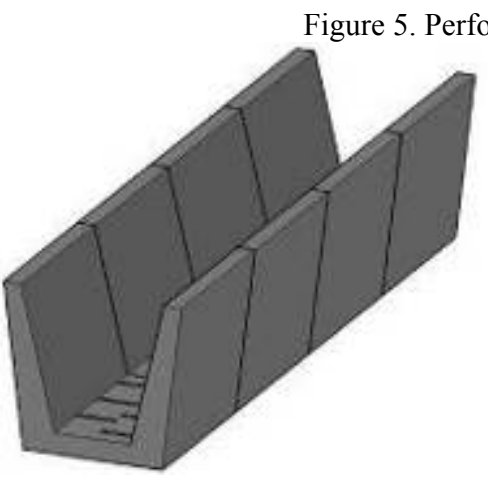

(a)

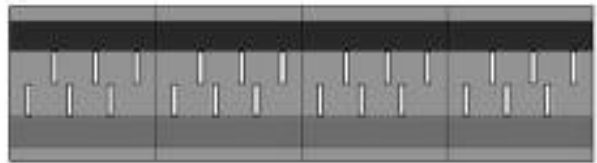

(b)

Figure 6(a). Perforated precast rainwater channel in 3D, (b) from below
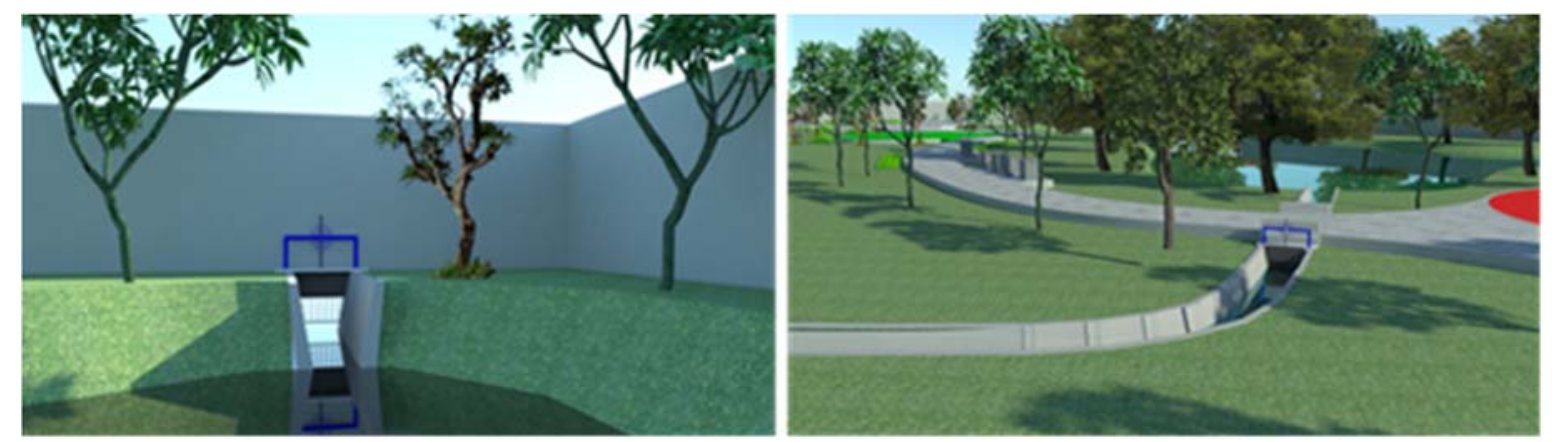

Figure 7. Perforated precast rainwater channel modelling in 3D Max Software 


\section{Lighting System}

Solar panel system (photovoltaic) is a device that consist of solar cells that convert sunlight to solar energy. As long as the solar panels operate in the sun, the energy of solar radiation is converted into electrical energy and there is an increase in the temperature of solar cells (Adeleke et.al, 2017). Some solar cells can be arranged in series or paraller and packaged un a unit called a module. Each solar cell consists of semiconductor elements that can absorsb photons from sunlight and convert them into electrical energy. In this community development project, the proposed lighting system is solar powered lighting system as described below:

a. Solar panel spesifications: Polycrystalline, VLRA battery is used as energy storage, capacity: 30 WP

b. Lighting spesifications: 7 Watt LED which is equal to 35 Watt, Color temperature: warm white 2700$7000 \mathrm{k}$ or pure white $6000-7000 \mathrm{k}$

The way solar powered lighting system are described below:

Solar panels can absorb photons from sunlight and convert them into electrical energy during the daylight. Voltage released by the solar panel is basically unstable. Thus, it needs a battery charge regulator that can regulate current for battery charging, avoid overcharging and avoid overvoltage. The recommended of battery type is VLRA type battery. In addition, this type of battery has a valve for gas exchange so that the temperature inside the battery will remain stable and the battery life will be maximal. The lamp types that are usually sold in the market are AC (alternating current) type, while the electricity output of solar panel is DC (direct current). Therefore, it also need an inverter device that is used to convert DC voltage to AC. The block diagram of solar panel system is shown in Figure 8.

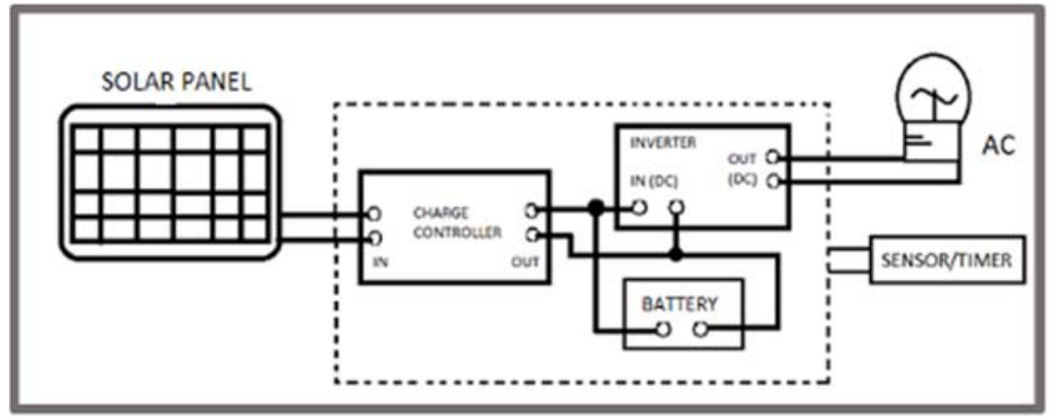

Figure 8. Solar panel block diagram

\section{Workshop}

The workshop is held at Forestry Office, South Jakarta, $22^{\text {nd }}$ November 2017. In this workshop, there are some activities such as presentation, discussion, and giving some souvenirs to the audience. Based on the Forestry Office feedback, the proposed design requires a slight modification to match the actual condition of Zodia Park.

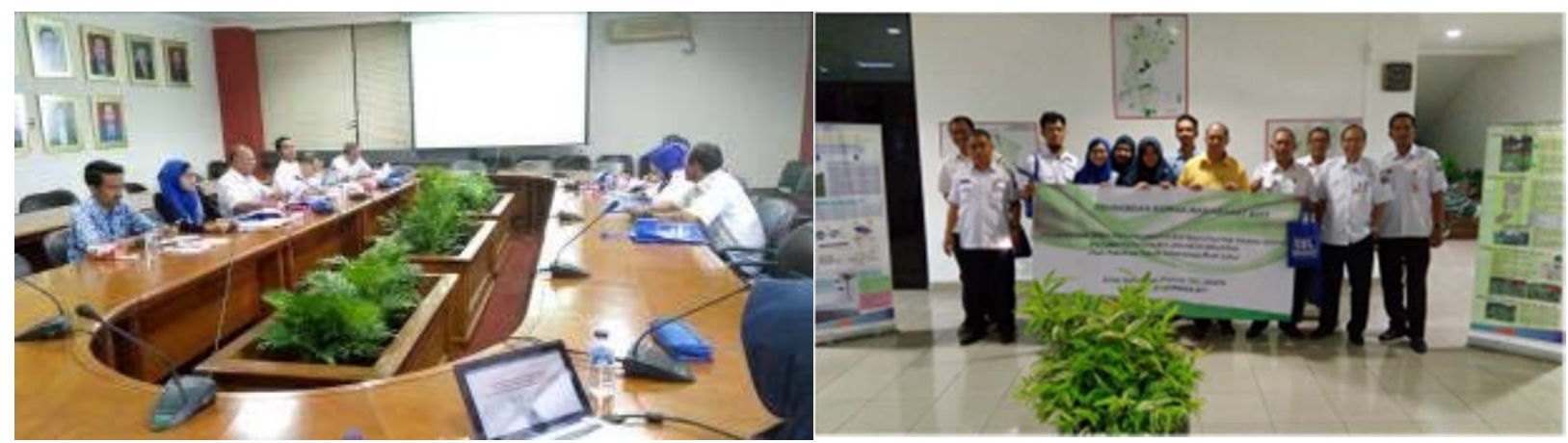

Figure 9. Workshop at Forestry Office, South Jakarta

\section{CONCLUSION}

This community service activities provides services for designing utility system at Zodia park, Petukangan Utara, South Jakarta. The design idea has been accepted by Forestry Service, DKI Jakarta. Besides, the feedback provided by the Forestry Service, DKI Jakarta can also broaden the community service team's insight so that there will be a harmonious understanding between the knowledge learned and the real conditions. 


\section{REFERENCES}

Adeleke D. K., Orotoye T. A. and Amuda D. B. (2017). "Experimental Evaluation of the Effect of Temperature on Polycrystalline and Monocrystalline Photovoltaic Modules," IOSR J. Appl. Phys., vol. 9, no. 2, pp. 510 . 